\title{
NUORTEN ASPERGER-AIKUISTEN OSALLISUUTTA ON VAHVISTETTAVA
}

\author{
Mari Kivistö: YTT, yliopistonlehtori, Lapin yliopisto \\ Kaisa Kuusikko: YTM, laillistettu sosiaalityöntekijä \\ Sini Sivonen: YTM, laillistettu sosiaalityöntekijä \\ mari.kivisto@ulapland.fi; kaisa.kuusik.ko@kempele.fi; sini.sivonen@ppshp.fi
}

Janus vol. 29 (2) 2021, 187-195

Henkilöt, joilla on neuropsykiatrisia erityispiirteitä, nähdään usein palvelujärjestelmän väliinputoajina (esim. Erityisvoimia -blogi; Mäenpää 2019). Esimerkiksi Asperger-piirteitä omaavia henkilöitä on asiakkaina muun muassa mielenterveyspalveluissa, aikuissosiaalityössä ja vammaispalveluissa, vaikkakaan kaikki Asperger-ihmiset eivät käytä tai tarvitse muita kansalaisia enempää terveyden- ja sosiaalihuollon palveluja.

Tarkastelemme puheenvuorossamme vammaispalvelujen asiakkaina olevien nuorten Asperger-aikuisten ${ }^{1}$ tilanteita osallisuuden näkökulmasta. Osallisuutta tarkastelemme erityisesti koulutus- ja työelämäosallisuutena sekä asiakas- ja palveluosallisuutena. Pohdimme, miten Asperger-piirteitä omaavat nuoret aikuiset tulevat autetuiksi nykyisessä palvelujärjestelmässä ja miten vammaispalvelujen sosiaalityön resursseilla ja palveluilla kyetään edistämään heidän osallisuuttaan. Tunnistamme rakenteellisten reunaehtojen vaikuttavan taustalla. Viime vuosina vammaispalvelujen sosiaalityötä ovat leimanneet suuret asiakasmäärät ja byrokratisoituminen (Laisi ym. 2017; Heini ym. 2019; Romakkaniemi ym. 2019).

Tutkimuskirjallisuuden rinnalla pohjaamme puheenvuoromme henkilökohtaiseen kokemukseemme vammaispalvelujen sosiaalityöstä. Koemme, että parhaimmillaan olemme työssämme kyenneet tukemaan nuorten Aspergeraikuisten osallisuutta kiinnostuksen ja välittämisen, luottamuksen rakentamisen, verkostoja hyödyntävän ammatillisen osaamisen sekä yksilöllisten palveluratkaisujen kautta. Toisaalta meillä on kokemuksia siitä, miten asiakkuus voi vammaispalvelujen sosiaalityön lisäksi olla aikuissosiaalityössä sekä mielenterveys- ja päihdepalveluissa asiakkaan tulematta siltikään autetuksi ja minkään tahon ottamatta kokonaisvastuuta. Hyödynnämme puheenvuorossa myös kolmen nuoren Asperger-aikuisen haastatteluja ${ }^{2}$.

\section{Tuen tarpeita}

Aspergerin oireyhtymä sisällytetään autismikirjoon. Tutkimusten perusteella moni helpottuu saadessaan diagnoosin kautta tilanteeseensa selitystä (esim.Vallikari 2011) ja useille Asperger muodostuu merkittäväksi osaksi identiteettiä (Smith \& Jones 2019; myös Sivonen 2007). Osa kuitenkin kokee diagnoosiinsa liittyen sekavia ja kielteisiä tunteita (Powell ym. 2016). Pahimmillaan diagnoosi voi stigmatisoida ja muodostua esimerkiksi työllistymisen esteeksi (Vallikari 2011). Toisaalta diagnoosi voi muodostua myös takeeksi välttämättömien palvelujen saamisessa esimerkiksi tilanteessa, jossa henkilö on työttömänä 
työnhakijana kykenemättä työn vastaanottamiseen (Hiilamo ym. 2017, 64).

Aspergeriin kuvataan usein liittyvän haasteita esimerkiksi vuorovaikutuksessa, toiminnanohjauksessa, päivä- tai vuorokausirytmissä ja stressinsietokyvyssä. Niin ikään on nostettu esille toiminnan kaavamaisuus ja poikkeuksellinen kiinnostus rajattuihin asioihin. Aistiärsykkeet voidaan kokea hankalina ja pakonomaiset rutiinit arjessa hallitsevina toimintakykyyn vaikuttaen. Aikuisiän pulmakohdiksi on tunnistettu psykososiaalisten valmiuksien vaihtelevuus, ajoittainen tuen tarve, työllistyminen, sosiaalisen- ja ammattiidentiteetin sekä aikuisen minäkuvan muodostaminen, vaikeudet ryhmätilanteissa, parisuhteen muodostaminen sekä itsenäisen elämänhallinnan vaatimukset. Suoriutuminen eri osa-alueilla on kuitenkin epätasaista voiden olla jollakin osa-alueella, esimerkiksi akateemisella, poikkeuksellisen hyvää. Mielenterveyden häiriöiden riskin on todettu olevan tavanomaista suurempi. (Sihvonen 2011; Vallikari 2011; Shavrina 2014; Appelqvist-Schmidlechner ym. 2017.)

Autismikirjon kokemustarinoissa korostuu tarve suhtautua kaikenlaisiin stereotypioihin varovasti (esim. Salokoski 2019). Sosiaalityön näkökulmasta Asperger voidaan tulkita ihmisen yhdeksi piirteeksi ja elämään heijastuvaksi tilannetekijäksi. Esimerkiksi haastatteluissa kohdatut kolme nuorta aikuista ${ }^{3}$ kertoivat tarvitsevansa tukea arjen hallinnassa.Tähän liittyi muun muassa järkevässä vuorokausirytmissä pysyminen, puuttuvien rutiinien aikaansaaminen, kodin askareiden suorittamiseen ryhtyminen sekä asioiden hoitaminen. Myös aloituskyvyn puutetta ja kommunikointivaikeuksia kuvattiin. Sosiaaliset verkostot eivät näyttäytyneet laajoina ja haastateltavat kertoivat vierastavansa uusia ihmisiä ja suuria ihmismassoja. Toisaalta itseä saatettiin kuvata "omalla tavalla sosiaalisena" tarkoittaen sitä, että tarvitsee kyllä verkostoonsa jonkin verran itselle merkityksellisiä ihmisiä, mutta ei välttämättä halua viettää paljoa aikaa näiden kanssa. Osa kertoi myös lapsuuden ja nuoruuden koulukiusaamiskokemuksista, jotka heijastuivat elämään ja omiin toimintatapoihin edelleen, esimerkiksi varovaisuutena sosiaalisen median käytössä.

\section{ESIMERKKEJÄ KOULUTUS- JA TYÖELÄMÄOSALLISUUDESTA}

Kokemustemme perusteella erityisen merkityksellisiä nuorille Aspergeraikuisille ovat nivelvaiheet, kuten lapsuudenkodista itsenäistyminen sekä opiskelemaan ja työelämään siirtyminen. Koulutustasossa ei yleensä ole eroa tavanomaiseen, ja esimerkiksi vallitseva korona-aika on lieveilmiöistään huolimatta voinut yksilöllisesti mahdollistaakin Asperger-nuorelle etäopetuksessa menestymistä ilman kasvokkaisen ryhmäopetuksen tuomia paineita. Kokemukset kuitenkin eriytyvät (Autismiliitto 2020). Työelämässä Aspergeraikuisilla on todettu syrjäytymistä ja tuen tarvetta (Sihvonen 2011; myös Vallikari 2011), mutta tarjolla oleva tuki on vähäistä, vaikka Asperger- ja muiden autismikirjon henkilöiden koulutus ja työllistyminen on yhteiskunnallisesti kannattavaa (Kirjanen ym. 2014). Sosiaalityössä olemme kohdanneet Asperger-ihmisiä, joilla on useitakin ammatillisia tutkintoja ja paljon annettavaa 
työelämälle ja yhteiskunnalle, mikäli niiden rakenteet olisivat ihmisten yksilölliset erityispiirteet paremmin huomioon ottavia.

Asperger-aikuisten on kuvattu voivan myös menestyä työelämässä, mutta esimerkiksi työn edellyttämä vuorokausirytmi, avokonttorit tai työpaikan sääntöjen tulkinta voivat tuottaa vaikeuksia (Vallikari 2011; Julian \& Barron 2019). Autismikirjon nuorten on todettu usein luopuvan unelma-ammateistaan tyytyen toissijaisiin, mutta itselleen sopivampina ja realistisempina pidettyihin ammatteihin (Nouf-Latif ym. 2019). Positiivista uutisointia edustaa Asperger-ihmisten työelämävahvuuksien korostaminen esimerkiksi ohjelmointi- ja koodausalalla, jolle on saatettu kouluttaa ja palkata nimenomaan Aspergertai muita autismikirjon henkilöitä (Yle 9.3.2020). Korona-aikana lisääntynyt etätyö on voinut joidenkin kohdalla parantaakin työelämäosallisuutta.

Kaikilla haastatelluilla nuorilla aikuisilla oli taustallaan ammatillinen koulutus. Tästä huolimatta he eivät olleet päässeet lainkaan osallistumaan palkkatyöhön lukuun ottamatta mahdollisia lyhyitä pätkä- tai kesätöitä. Haastateltavien suhtautuminen työelämään vaihteli. Nuorin heistä osallistui kuntouttavaan työtoimintaan mutta näki, ettei hän tule selviytymään nykyisen kaltaisessa itseä liikaa rasittavassa työelämässä ainakaan ilman tukitoimia, kuten tukihenkilöä ja työtehtävien pilkkomista keskittymiskyvyn ehdoilla pieniin palasiin. Lisäksi työn tulisi olla itseä kiinnostavaa. Työtoimintaan hän kertoi osallistuvan- sa lähinnä "paperisodan" välttääkseen. Toinen, työkyvyttömyyseläkkeelle siirtymässä ollut nuori aikuinen, olisi halunnut olla mukana työelämässä, mutta myös hän kuvasi työelämän olevan toimintakäytännöiltään, vaatimuksiltaan ja asenteiltaan omalle selviytymiselleen mahdoton. Työkyvyttömyyseläkkeellä oleva kolmas henkilö nimesi eläkkeen hyväksi puoleksi pysyvän toimeentulon, mutta kielteiseksi tekijäksi eläkkeen ihmistä kokonaisvaltaisesti määrittävän statuksen, joka estää töihin pääsyn myös jatkossa, vaikka työhaluja olisikin. Toisaalta haastateltavat saattoivat palkkatyön sijaan kuvata muuta, omia mielenkiinnon kohteita vastaavaa, mielekkääksi kokemaansa elämäntoimintaa sekä tähän liittyviä tulevaisuuden suunnitelmia.

Kokemustemme mukaan on ensisijaisen tärkeää, että nuoret Asperger-aikuiset löytävät oman vahvuusalueensa ja että he voivat kanavoida erityisosaamistaan jollakin tavalla. Motivaatio itseä kiinnostavien töiden tekemiseen on suuri ja näiden voimavarojen käyttöönotto on tärkeää sekä henkilöiden itsensä että työelämän ja koko yhteiskunnan kannalta. Kokemustemme perusteella hyviä käytäntöjä nuorten Aspergeraikuisten kanssa toimiessa ovat muun muassa monialainen yhteistyö TEpalvelujen kanssa, kolmannen sektorin järjestämän työelämävalmennuksen hyödyntäminen sekä kunnan järjestämä avotyö. Avotyön näemme ennen kaikkea väliaikaisena etappina itselle sopivaan palkkatyöhön pääsyn polulla sekä mahdollisuutena antaa näyttöjä potentiaaliselle työnantajalle. 
NÄKEMYKSIÄ SOSIAALITYÖN ASIAKKUUDESTA

Lisääntynyt autismikirjon diagnosointi on tuottanut myös sosiaalityölle haasteita palvelutarpeisiin vastaamisessa (Mogro-Wilson 2014). Sosiaalityössä tärkeää on lähestyä asiakkaita diagnoosin sijaan ihmisinä (Shavrina 2014) huolimatta siitä, että diagnoosi edelleen usein määrittää sitä, mihin sosiaalityön lohkoon asiakas ohjataan. Esimerkiksi vammaispalvelujen saamiselle diagnoosi ei ole edellytys, mutta vammaispalvelujen käytänteissä vaikeuksien johtuminen vammasta tai sairaudesta yleensä todetaan lääkärin tekemän diagnoosin kautta. Jos ihmisen tilanne suhteessa ympäristön ominaisuuksiin ja vaatimuksiin aiheuttaa pitkäaikaisia ja erityisiä tuen tarpeita, ovat vammaispalvelut tulkittavissa luonnolliseksikin tukea järjestäväksi tahoksi. Kaikki Aspergerihmiset eivät kuitenkaan miellä itseään vammaisina henkilöinä (Smith \& Jones 2019).

Myös meillä on kokemuksia siitä, miten aikuisiällä vammaispalvelujen asiakkaaksi tulleella voi identifioituminen vammaispalvelujen asiakkaaksi olla hankalaa. Eräs haastateltavista pohti, onko Asperger "sellanen varsinainen vamma vai onko tämä neurologinen sairaus että, oon vähän tällai niinku väliinputoaja tässä -- olenko nyt ihan oikeassa paikassa sen suhteen, että täällä vammaispalveluissa --”. Mikäli ihminen kokee olevansa asiakkaana väärässä paikassa, voi asiakkuus jäädä etäiseksi ja tarvittava tuki saamatta. Toisaalta olemme nähneet myös tilanteita, joissa Asperger-ihminen kokee itsensä nimenomaan vammaiseksi henkilöksi ja turhautuu, kun joutuu vakuuttele- maan sitä palvelujärjestelmälle saadakseen vammaispalveluista tukea.

Näemme tilanteen osin ristiriitaisena, sillä yhtäältä juuri vammaispalvelujen sosiaalityössä voidaan ajatella olevan osaamista järjestää palveluja asiakkaiden yksilölliset tilanteet ja tarpeet huomioiden. Toisaalta sosiaalihuoltolain (1301/2014) mukaiset palvelut, kuten ohjaajapalvelut tai tukihenkilöpalvelu, voivat tukea Asperger-henkilöä perinteisiä vammaispalveluja, kuten henkilökohtaista apua, paremmin. Koemmekin uudistuneen sosiaalihuoltolain parantaneen palveluvalikoimaa, ja parhaimmillaan sosiaalityöntekijällä on taustaorganisaatiosta riippumatta mahdollisuus järjestää palveluja ja tukitoimia usean eri lain nojalla ja yksilöllisesti räätälöiden. Heikoimmillaan palvelujärjestelmä voi muodostua hylkiväksi, sillä Asperger-ihmisten ja heidän omaistensa kokemuksissa kuvataan usein palvelujärjestelmän hajanaisuutta sekä juuri vammaispalveluista esimerkiksi ilman kehitysvammadiagnoosia tai "näkyvää vammaa" saatuja hylkääviä päätöksiä ja näiden johdosta läpikäytyjä raskaita valitusprosesseja.

Haastateltavat olivat ennen vammaispalveluasiakkuuttaan olleet asiakkaina muun muassa työvoima- ja mielenterveyspalveluissa sekä nuorisopsykiatrian palveluissa. Heillä oli aiempia kokemuksia myös Kelan kuntouttavista projekteista. Haastatteluhetkellä järjestetyt arjen tukitoimet tulivat vammaispalveluista. Haastateltavien kokemuksissa tuli näkyväksi, miten vammaispalvelujen asiakkuuteen voidaan päätyä muiden tahojen yksi kerrallaan määritettyä omat tukitoimensa läpikäydyiksi tai epäsopiviksi. Eräs haastateltava kertoi 
omaa vammaispalveluasiakkuuttaan edeltäneen muun muassa hankalien koulukokemusten, neurologisen kuntoutuksen sekä työvoimapalvelujen asiakkuuden. Vammaispalveluihin siirtymistä oli lopulta ehdottanut työvoimapalvelujen psykologi. Haastateltava suhtautui tulevaisuuteensa melko positiivisesti, mutta palvelujärjestelmää tuntevaa haastattelijaa jäi pohdituttamaan, mahdollistuuko asiakkaalle vammaispalvelujen asiakkuudessa varmuudella hänen kykyjensä, potentiaalinsa, toiveidensa ja suunnitelmiensa mukainen tulevaisuus. Vammaispalvelujen asiakkuuden ei myöskään pidä tarkoittaa sitä, että muut palvelut luovuttavat ja siirtävät vastuun yksinomaan vammaispalvelulle. Kokemustemme perusteella eri toimijoiden yhteistyö tyrehtyy joskus resurssien puutteesta johtuvaan palvelujärjestelmän sisäiseen kamppailuun, jossa jokainen itseltä ja omalta sektorilta pois siirtyvä asiakas tarkoittaa hieman enemmän aikaa muiden asiakkaiden asioiden hoitamiseen.

\section{KoKeMUKSIA ASIAKAS- JA PALVELUOSALLISUUDESTA}

Vammaispalvelujen sosiaalityön tehtävänä on tukea asiakkaita elinympäristöissään - niin kotona kuin myös koulussa ja työssä tai muussa elämän toiminnassa (Vanbergeijk \& Shtayermann 2005; Shavrina 2014; Romakkaniemi ym. 2018). Resurssivajeen vuoksi työstä on kuitenkin paikoin tullut kiireistä palveluohjausta ja palvelutarpeen arviointien tekemistä (esim. Laisi ym. 2017; Heini ym. 2019; Romakkaniemi ym. 2019).
Kaikki haastateltavat eivät olleet edes tavanneet sosiaalityöntekijää. Osa kuvasi vaikeutta yhteydensaamisessa sosiaalityöntekijään sekä hitautta avunpyyntöihin vastaamisessa. Asiointi vaikutti perustuvan asiakkaan omaan aktiivisuuteen ja mukautumiseen "oikeanlaisiin toimintatapoihin". Eräs haastateltava kertoi hakeneensa vammaispalveluista ryhmämuotoista palvelua sosiaalisten taitojen ja suhteiden vahvistamiseksi ja "erakoitumisensa estämiseksi". Hänelle kerrottiin hänen täyttäneen väärän hakemuslomakkeen. Lisäksi työntekijät olivat epäilleet jo hakemusta jätettäessä, ettei tällaista palvelua ole vammaispalveluista saatavissa ja häntä kehotettiin hakemaan palvelua muualta. Haastateltava kuvasi tilannetta seuraavasti:"sit kävi ilmi, että ei heillä oikeestaan tunnu olevan minun diagnoosille palvelua". Myös omien kokemustemme mukaan työntekijällä on usein käytössä tietty palveluvalikoima, josta hän koettaa valita asiakkaan tuen tarpeeseen sopivimman palvelun. Mahdollisuus tuen tarpeeseen vastaamiseen jollain aivan muulla tavalla ei aina onnistu, ainakaan helposti.

Osa asiakkaista kokee, että vammaispalvelun sosiaalityöntekijöillä pitäisi olla enemmän tietoa erilaisista sairauksista ja vammoista (Heini ym. 2019). Myös yksi haastateltavista kuvasi, miten sosiaalialan ammattilaisilla olisi hyvä olla enemmän tietoa autismikirjon häiriöistä. Toisaalta hänellä riitti ymmärrystä ammattilaisille: "niitä erityisominaisuuksia on kyllä sellanen kirjo, että yhdelle henkilölle ne aiheuttais vaan päänsärkyä siin vaiheessa, jos yrittää muistaa kaikki seuraaval kerralla". Vammaisuuden kirjon laajuus edellyttää vammaispalvelun sosiaali- 
työntekijöiltä laajaa tietopohjaa (Romakkaniemi ym. 2018), mutta tietoa esimerkiksi autismikirjoon kuuluvien henkilöiden tarpeista on tuotavissa sosiaalityöhön myös korostamalla holistisen sosiaalityön oman ytimen mukaisesti ennen muuta ihmisoikeuksia, osallisuutta, elämänlaatua ja hyvää kohtaamista (Kangas 2014; Mogro-Wilson ym. 2014). Laki sosiaalihuollon ammattihenkilöistä $(817 / 2015)$ edellyttää toimenpiteitä ammattipätevyyden ylläpitämisen ja osaamisen kehittämisen suhteen sekä työnantajalta että sosiaalityöntekijöiltä. Myös sosiaalityön ja terveydenhuollon yhteistyö parhaimmillaan laajentaa ymmärrystä molemmin puolin ja auttaa paremmin ymmärtämään asiakkaan tilannetta.

Kaikki haastateltavat saivat vammaispalveluista asumisen ohjaus -palvelua. Osalla oli myös tukihenkilö. Palveluilla tavoiteltiin sujuvampaa arkea sekä selkeyden tuomista arjen rytmiin ja rutiineihin. Palvelun toteuttaminen ei kuitenkaan aina sujunut ongelmitta. Yksi haastateltava olisi halunnut enemmän palvelua, mutta koki lisäpalvelujen hakemisen hankalaksi ja byrokraattiseksi. Toisella oli ongelmia palvelun toteuttamisen, kuten ajankohtien sopimisessa: "Kerran jopa kävi niin, että siel oli pari ihmistä sairastunu eikä kukaan huomannu ilmoittaa, että koko viikkona ei kukaan pääse". Lisäksi saatettiin kokea osan ammattilaisista avustavan kaikkia vammaispalveluasiakkaita kategorisesti samalla tavalla. Osa oli kokenut kielteisesti työntekijöiden vaihtuvuuden. Kokemustemme mukaan onkin tärkeää, että hyödynnetään pitkäaikaisia auttamissuhteita, ja että ammattilaisilla on tietoa Aspergeriin liittyvistä erityispiirteistä, kuten vaikeuksista sosiaalisissa suhteissa ja tuttujen rutiinien merkityksestä (myös Sihvonen 2011).

Nuori aikuinen ei aina välttämättä itsekään tiedä, mikä ongelma on tai miten sen sanoittaisi. Asperger-henkilöillä voi olla vaikeuksia vuorovaikutuksessa. Osa on ilmaisuissaan ja puheiden tulkinnassaan hyvinkin suoraviivaisia, joten heidän kanssaan toimiminen voi poiketa muiden asiakkaiden kanssa toimimisesta ja olla siksi työntekijöiden kokemana haastavaa. Sosiaalityössä kuitenkin tarvitaan avointa mieltä ja "menemistä myös mahdollisen diagnoosin yli" (ks. Shavrina 2014; myös Kangas 2014). Jos asiakkaan ominaisuudet ja vaikeudet näkee vain Aspergerin kautta, voi ihminen jäädä kohtaamatta itsenään ja hänen vaikeutensa sekä niiden todelliset syyt huomaamatta.

\section{SOSIAALITYÖ OSALLISUUDEN VAHVISTAJANA}

Olemme pyrkineet puheenvuorossamme avaamaan nuorten Aspergeraikuisten osallisuuden haasteita sekä sosiaalityön mahdollisuuksia heidän osallisuutensa vahvistamiseksi. Nykyisen palvelujärjestelmän ollessa pirstaleinen on esitetty kysymys siitä, voisiko kuntien sosiaalityö olla se taho, joka ottaa kokonaisvastuun koulutuksesta ja työstä syrjään jääneiden nuorten palvelujen koordinoimisesta erityisesti työelämään pääsyn nivelvaiheessa (Hiilamo ym. 2017, 64, 72). Vammaispalvelujen sosiaalityön näkökulmasta haasteen vastaanottamista vaikeuttavat rajalliset resurssit (ks. Laisi ym. 2016; Romakkaniemi ym. 2018) sekä vallitseva työorientaatio palvelujen koordinointi- ja byrokratiatyönä (Romakkaniemi ym. 2019; myös Kivistö \& Hokkanen, tu- 
lossa). Auttamisessa tarvittavaa osaamistakaan ei välttämättä pääse syntymään kuormittuneessa työtilanteessa, jota leimaa myös työntekijöiden vaihtuvuus. Toisaalta toimintakäytännöt ovat paikallisesti vaihtelevia ja osassa kuntia on olemassa hyviä käytäntöjä neuropsykiatrisia erityispiirteitä omaavien henkilöiden auttamiseksi.

Osa nuorista Asperger-aikuisista voisi erityisesti hyötyä asiakassuhteeseen panostavasta ja asiakkaan valtaistamiseen tähtäävästä tarpeen mukaan rinnalla kulkevasta sosiaalityöstä. Monella saattaa olla takanaan niin elämässä kuin palvelujärjestelmän asiakkuudessakin koettuja aiempia, varauksellisuutta tuottaneita pettymyksiä (ks. MogroWilson ym. 2014; myös Kangas 2014; Kivistö \& Hokkanen 2020). Vammaispalvelujen sosiaalityö järjestää osana palveluohjausta ja hallinnollisilla päätöksillään nuorille Asperger-aikuisille tukea eri palveluntuottajilta. Meitä kiinnostaa myös se, millaista voisi parhaimmillaan olla palvelutarpeet yksilöllisesti ja kokonaisvaltaisesti huomioon ottava vammaispalvelujen sosiaalityö sekä osallisuuden vahvistamiseen koulutettujen sosiaalityöntekijöiden panos nuorten Asperger-aikuisten tukemisessa (myös Vallikari 2011). Jokaisella nuorella aikuisella on yhdenvertainen oikeus kaikkiin osallisuusmahdollisuuksiin sen sijaan, että joidenkin elämänkulkuja polutetaan kategorisesti tietynlaisiksi. Tämä edellyttää riittäviä sosiaalityön resursseja laajasti ymmärrettynä sekä sosiaalityön ytimestä ammentavaa työorientaatiota.

\section{ViITTEET}

1 Puheenvuorossa käytetään käsitteitä "nuori Asperger-aikuinen" ja "Aspergerihminen" tiedostaen se kritiikki, joka kategorisoimiseen kohdistuu. Perustelemme käsitteen käyttöä tarpeella nostaa esiin juuri tämän asiakasryhmän tilanteita ja tarpeita.

2 Mari Kivistö on toteuttanut haastattelut vuonna 2018.

3 Osalla haastateltavista oli Aspergerin lisäksi myös muita diagnooseja.

\section{KirjallisuUs}

Appelqvist-Schmidlechner, Kaija \& Lämsä, Riikka \& Tuulio-Henriksson, Annamari (2017) Oman väylän kulkijat. Kelan neuropsykiatrisen kuntoutuksen aloittaneiden nuorten aikuisten psykososiaalinen hyvinvointi. Työpapereita 120. Helsinki: Kela.

Autismiliitto 2020. Autismiliiton kysely perheiden hyvinvoinnista keväällä 2020: Perheiden kokemukset korona-arjesta jakaantuivat. https://www.autismiliitto. fi/liitto/ajankohtaista/autismiliiton_kysely_perheiden_hyvinvoinnista_kevaal1a_2020_perheiden_kokemukset_korona-arjesta_jakaantuivat.3751.news. Luettu 3.5.2021.

Erityisvoimia -blogi. https://erityisvoimia. $\mathrm{fi} /$ blogi/. Luettu 30.9.2020.

Heini,Annina \& Hokkanen, Liisa \& Kontu, Katariina \& Kunttu, Katriina \& Ronimus, Heli (2019) Osallisuus vammaissosiaalityössä on yhteistyötä - asiakkaiden kokemuksia. Lapin yliopiston yhteiskuntatieteellisiä julkaisuja B. Tutkimusraportteja ja selvityksiä 67 . Rovaniemi: Lapin yliopisto.

Hiilamo, Heikki \& Määttä, Anne \& Koskenvuo, Karoliina \& Pyykkönen, Jussi \& Räsänen, Tapio \& Aaltonen, Sanna (2017) Nuorten osallisuuden edistäminen. Selvitysmiehen raportti. Puheenvuoroja 11. Tampere: Diakonia-ammattikorkeakoulu.

Julian, Anna \& Barron, Ronda (2019) Employees with Asperger`s syndrome and their experiences within the work environment. DBS Business Review 3, 
30-48. https://doi.org/10.22375/dbr. v3i0.58

Kangas, Kaisa (2014) Asiakkaan ja sosiaalityöntekijän kohtaaminen Asperger-aikuisen näkökulmasta. Pro gradu -tutkielma. Rovaniemi: Lapin yliopisto. http://urn. fi/URN:NBN:fi:ula-201406251341 Luettu 12.10.2020.

Kirjanen, Svetlana \& Tuulio-Henrikssson, Annamari \& Autti-Rämö, Ilona (2014) Miten tukea opintoja ja työllistymistä kun nuorella on autisminkirjon häiriö? Potilaan lääkärilehti 30.9.2014. https:// www.potilaanlaakarilehti.fi/artikkelit/ miten-tukea-opintoja-ja-tyollistymistakun-nuorella-on-autismikirjon-hairio/. Luettu 30.9.2020.

Kivistö, Mari \& Hokkanen, Liisa (2020) Valtavirtateknologioita käyttävien vammaisten henkilöiden eriytyvät toimijuudet sähköisten vammaispalveluiden käyttäjinä. Finnish Journal of eHealth and eWelfare 12 (1), 44-56. https://doi. org/10.23996/fjhw.86948

Kivistö, Mari \& Hokkanen, Liisa, tulossa 2021. Asiakaskansalaisuus vammaissosiaalityössä. Teoksessa Antti Teittinen, Mari Kivistö, Merja Tarvainen \& Sanna Hautala (toim.) Vammaiset ihmiset kansalaisina. Tampere:Vastapaino.

Laisi, Nina \& Lappalainen, Tiina \& Vauramo, Mirja (2016) Selvitys vammaispalveluiden sosiaalialan ammattilaisten näkemyksistä. Invalidiliitto ry \& Talentia ry. https://www.invalidiliitto.fi/sites/ default/files/2017-01/vammaispalvelun_sosiaalialan_ammattilaiset-selvitys. pdf. Luettu 30.9.2020.

Laki sosiaalihuollon ammattihenkilöistä $817 / 2015$.

Mogro-Wilson, Cristina \& Davidson, Kay \& Bruder, Mary Beth (2014) An empowerment approach in teaching a class about autism for social work students. Social Work Education 33 (1), 61-76. https://doi.org/10.1080/02615479.201 2.734802

Mäenpää, Nina (2019) Järjestelmä on rikki. Nepsy-lapsia syrjäytetään yhteiskunnasta. Dialogi -blogi 18.12.2019. https://dialogi.diak.fi/2019/12/18/jarjestelma-onrikki-nepsy-lapsia-syrjaytetaan-yhteiskunnasta/. Luettu 30.9.2020.

Nouf-Latif, Faten \& Bertilsdotter-Rosqvist,
Hanna \& Markström, Urban (2019) Narratives of ideal and second-option jobs among young adults with high functioning autism. Nordic Social Work Research 9 (2), 104-117. https://doi.org /10.1080/2156857X.2018.1484385

Powell, Trevor \& Acker, Louise (2016) Adults` experiences of an Asperger syndrome diagnosis:Analysis of its emotional meaning and effect on participants` lives. Focus on Autism and Other Developmental Disabilities 31 (1), 72-80. https:// doi.org/10.1177/1088357615588516

Romakkaniemi, Marjo \& Martin, Marjatta \& Könkkölä, Kalle \& Lappalainen, Tiina (2018) Vammaispalvelujen sosiaalityön asiantuntijuus on turvattava. Yhteiskuntapolitiikka 83 (3), 338.

Romakkaniemi, Marjo \& Martin, Marjatta \& Lappalainen, Tiina (2019) Vammaissosiaalityön asiantuntijuus harkintavallan perustana. Teoksessa Anneli Pohjola, Tarja Kemppainen, Asta Niskala \& Nina Peronius (toim.) Yhteiskunnallisen asemansa ottava sosiaalityö. Tampere: Vastapaino, 171-198.

Salokoski, Leena (2019) Omanlaisensa aikuinen. Autismiliiton tarinat. https:// www.autismiliitto.fi/liitto/autismi-lehden_sivuilta/tarinat/omanlaisensa_aikuinen.3453.news?3223 o=10 Luettu 12.10.2020.

Shavrina, Natalia (2014) Beyond the other`s world: an essay about the experience of social work with a diagnosis of Asperger syndrome. Journal of Comparative Social Work 9 (1), 109-126. https://doi. org/10.31265/jcsw.v9i1.112

Sihvonen, Janne (2011) Aikuisen Aspergerpotilaan neuropsykiatrinen valmennus yksilökuntoutuksena. Lääketieteellinen aikakauskirja Duodecim 127 (2), 118 125.

Sivonen, Sini (2007) Diagnoosin merkitys Asperger-aikuiselle. Pro gradu -tutkielma. Lapin yliopisto.

Smith, Olivia \& Jones, Sandra C. (2019) 'Coming out' with autism: Identity in people with an Asperger`s diagnosis after DSM-5. Journal of Autism and Developmental Disorders, 592-602. https://doi. org/10.1007/s10803-019-04294-5

Sosiaalihuoltolaki 1301/2014.

Yle (2020) Aspergerin oireyhtymä voi olla 
vahvuus työelämässä - esimerkiksi tarkassa koodarin työssä autismin kirjon ihminen pärjää paremmin kuin moni muu. https://yle.fi/uutiset/3-11197771 Luettu 30.9.2020.

Vallikari, Aila (2011) Miten tulla kuulluksi ja ymmärretyksi? Asperger-aikuisten kokemuksia avun hakemisesta sosiaali- ja mielenterveyspalveluista. Pro gradu -tutkielma. Tampereen yliopisto. Yhteiskun- ta- ja kulttuuritieteiden yksikkö. https:// trepo.tuni.fi/handle/10024/82989. Luettu 12.10.2020.

Vanbergeijk, Ernst O. \& Shtayermann, Oren (2005) Asperger`s syndrome. An enigma for social work. Journal of Human Behaviour in the Social Environment 12 (1), 23-37. https://doi.org/10.1300/ J137v12n01_02 